\title{
Performance of Glass Woven Fabric Composites with Admicellar-Coated Thin Elastomeric Interphase
}

\author{
Harry J. Barraza $^{(a)}$, Youssef K. Hamidi ${ }^{(b, c) *}$, Levent Aktas ${ }^{(b)}$, Edgar A. O'Rear ${ }^{(a)}$, and M.C. Altan ${ }^{(b)}$ \\ (a) School of Chemical Engineering and Materials Science, University of Oklahoma, Norman, OK 73019 \\ (b) School of Aerospace and Mechanical Engineering, University of Oklahoma, Norman, OK 73019 \\ ${ }^{(c)}$ Ecole Nationale Supérieure des Mines de Rabat, Agdal, Rabat Morocco \\ * Corresponding author. E-mail: hamidi@ou.edu
}

\section{ABSTRACT}

Adequate stress transfer between the inorganic reinforcement and surrounding polymeric matrix is essential for achieving enhanced structural integrity and extended lifetime performance of fiber-reinforced composites. The insertion of an elastomeric interlayer helps increase the stress-transfer capabilities across the fiber/matrix interface and considerably reduces crack initiation phenomena at the fiber ends. In this study, admicellar polymerization is used to modify the fiber/matrix interface in glass woven fabric composites by forming thickness-controlled poly(styrene-co-isoprene) coatings. These admicellar interphases have distinct characteristics (e.g., topology and surface coverage) depending on the surfactant/monomer $(\mathrm{S} / \mathrm{M})$ ratios used during the polymerization reaction. Overall, the admicellar coatings have a positive effect on the mechanical response of resin transfer molded (RTM), E-glass/epoxy parts. For instance, ultimate tensile strength (UTS) of composites with admicellar sizings improved 50 to $55 \%$ over the control desized samples. Interlaminar shear strength (ILSS) also showed increases ranging from 18 to $38 \%$ over the same control group. Interestingly, the flexural properties of these composites proved sensitive to the type of interphase formed for various admicellar polymerization conditions. Higher surface coverage and film connectedness in admicellar polymeric sizings are observed to enhance stress transfer at the interfacial region.

Keywords: admicellar polymerization, elastomeric interphases, thin films, poly(styrene-coisoprene), surfactants, fiber-reinforced polymer composites, resin transfer molding (RTM). 


\section{References}

1. Atkins AG. Intermittent bonding for high toughness/ high strength composites. J Mater. Sci. 1975; 10: 819-832.

2. Marom G, Arridge RGC. Stress concentrations and transverse modes of failure in composites with a soft fibre-matrix interlayer. Mater. Sci. Eng. 1976; 23: 23-32.

3. Arridge RGC. The effect of interlayers on the transverse stresses in fiber composites. Polym. Eng. Sci. 1975; 15: 757-760.

4. Jao SH, Mcgarry FJ. Interphase bond strength and energy absorption of injection-molded rubber-coated glass/nylon composites. J. Reinf. Plast. Compos. 1992; 11: 811-835.

5. Mcgarry FJ. Polymer composites. Annu. Rev. Mater. Sci. 1994; 24: 63-82.

6. Labronici M, Ishida $\mathrm{H}$. Toughening composites by fiber coating: a review. Compos. Interfaces 1994; 2: 199-234.

7. Vörös G. , Pukánszky B. Effect of a soft interlayer with changing properties on the stress distribution around inclusions and yielding of composites. Compos. A 2001; 32: 343-352.

8. Matonis VA, Small NC. A macroscopic analysis of composites containing layered spherical inclusions. Polym. Eng. Sci. 1969; 9: 90-99.

9. Hayes SA, Lane R, Jones FR. Fibre/matrix stress transfer through a discrete interphase. Part 1: single-fibre model composites. Compos. A 2001; 32: 379-389.

10. Yosomiya R, Morimoto K, Nakajima A, et al. Adhesion and bonding in composites. Mater. Manuf. processes 1992; 7: 153-155.

11. Woo MS, Piggott MR. Water absorption of resins and composites: II. Diffusion in carbon and glass reinforced epoxies. J. Compos. Technol. Research 1987; 9: 162-166.

12. Yoshida W, Cohen Y. Topological AFM characterization of graft polymerized silica membranes. J. Membrane Sci. 2003; 215: 249-264.

13. Karger-Kocsis J, Mahmood H, Pegoretti A. Recent advances in fiber/matrix interphase engineering for polymer composites. Progress in Mat. Sci. 2015; 73: 1-43.

14. Jones FR. Wiley encyclopedia of composites. John Wiley \& Sons: New York; 2012. Chapter 2, Adhesion aspects in composites; p. 11-21.

15. Bekyarova E, Thostenson ET, Yu A, et al. Multiscale carbon nanotube-carbon fiber reinforcement for advanced epoxy composites. Langmuir. 2007; 23: 3970-3974 (2007).

16. Rodriguez AJ, Guzman ME, Lim CS, et al. Mechanical properties of carbon nanofiber/fiberreinforced hierarchical polymer composites manufactured with multiscale-reinforcement fabrics. Carbon. 2011; 49: 937-948.

17. Tang G, Zang Z, Chang D, et al. Study on the interfacial behavior of clay-coated carbon fiberreinforced PEI composites. Polym-Plast Technol. Engr. 2012; 51: 861-865.

18. Zhang S, Liu W, Wang J, et al. Improvement of interfacial properties of carbon fiber-reinforced poly(phthalazinone ether ketone) composites by introducing carbon nanotube to the interphase. Polym Compos. 2015; 36: 26-33.

19. Jin L, Zhang L, Su D, et al. Direct Growth of Aligned Carbon Nanotubes on Quartz Fibers for Structural Epoxy Composites. Indus. Engr. Chem. Research 2012; 51: 4927-4933.

20. Wang B, Gao Y. Matrix formulation and interfacial enhancement of an aeronautical carbon fabric/epoxy composites fabricated via resin transfer molding (RTM) technique. J. Adh. Sci. Tech. 2016; 30: 75-88.

21. Ma L, Wu L, Cheng X, et al. Improving the interlaminar properties of polymer composites using a situ accumulation method to construct the multi-scale reinforcement of carbon nanofibers/carbon fibers. Compos. A 2015; 72: 65-74. 
22. Wang C, Ji X, Roy A, et al. Shear strength and fracture toughness of carbon fibre/epoxy interface: effect of surface treatment. Mater. Design 2015; 85: 800-807.

23. Xua Y, Hea QC, Gu ST. Effective elastic moduli of fiber-reinforced composites with interfacial displacement and stress jumps. Intern. J. Solids \& Struc. 2016; 80: 146-157.

24. Upadhyaya P, Kumar S. 24-Micromechanics of stress transfer through the interphase in fiberreinforced composites. Mechanics of Mater. 2015; 89: 190-201.

25. Wang $\mathrm{W}$, Liu $\mathrm{H}$, Cheng $\mathrm{H}$, et al. Interface engineering of fiber-reinforced all-oxide composites fabricated by the sol-gel method with fugitive pyrolytic carbon coatings. Compos. B 2015; 75: 86-94.

26. Gao X, Gillespie JW Jr., Jensen RE, et al. Effect of fiber surface texture on the mechanical properties of glass fiber reinforced epoxy composite. Compos. A 2015; 74: 10-17.

27. Liu Z, Zhang L, Yu E, et al. Modification of glass fiber surface and glass fiber reinforced polymer composites challenges and opportunities: from organic chemistry perspective. Current Organ. Chem. 2015; 19: 991-1010.

28. Dey M, Deitzel JM, Gillespie Jr JW, et al. Influence of sizing formulations on glass/epoxy interphase properties. Compos. A 2014; 63: 59-67.

29. Carlier V, Sclavons M, Jonas AM, et al. Probing thermoplastic matrix-carbon fiber interphases. 1. Preferential segregation of low molar mass chains to the interface. Macromolecules 2001; 34: 3725-3729.

30. Gamstedt EK, Skrifvars M, Jacobsen TK, et al. Synthesis of unsaturated polyesters for improved interfacial strength in carbon fibre composites. Compos. A 2002; 33: 1239-1252.

31. Zhang J, Deng S, Wang Y, et al. Effect of nanoparticles on interfacial properties of carbon fibre-epoxy composites. Compos. A 2013; 55: 35-44.

32. Hossain MK, Chowdhury MMR, Salam MB, et al. J. Improved thermomechanical properties of carbon fiber reinforced epoxy composite using amino functionalized XDCNT. Appl. Polym. Sci. 2014; 131: 40709 (1-12).

33. Tillie MN, Lam TM, Gerard JF. Insertion of an interphase synthesised from a functionalised silicone into glass-fibre/epoxy composites. Compos. Sci. Technol. 1998; 58: 659-663.

34. Peiffer DG, Impact strength of thick-interlayer composites. J. Appl. Polym. Sci. 1979; 24 : 1451-1455.

35. Sakhalkar S, Hirt D. Admicellar Polymerization of Polystyrene on Glass Fibers. Langmuir 1995; 11: 3369-3373.

36. Grady BP, O’Rear EA, Penn L, et al. Admicellar Polymerization of Styrene-Isoprene on Glass Cloth for Use in Composite Manufacture. Polym. Compos. 1998; 19: 579-.

37. Barraza HJ, Hwa M, Blakley K, et al. Wetting behavior of elastomer-modified glass fibers. Langmuir 2001; 17: 5288-5296.

38. Barraza HJ, Olivero KA, Hamidi YK, et al. Elastomeric sizings for glass fibers and their role in fiber wetting and adhesion in resin transfer molded composites. Compos. Interfaces 2002; 9: 477-507.

39. Barraza HJ, Aktas L, Hamidi YK, et al. Moisture absorption and wet adhesion properties of resin transfer molded (RTM) composites containing elastomer-coated glass fibers. J. Adh. Sci. Technol. 2003; 17: 217-242.

40. Blakley KL, Grady BP, O’Rear EA. Effects of styrene-isoprene copolymer glass fiber coatings on woven glass cloth epoxy composite performance. Polym. Comp. 2004; 25: 82-93. 
41. Funkhouser G, Arevalo M, Glatzhofer D, et al. Solubilization and adsolubilization of pyrrole by sodium dodecyl sulfate: polypyrrole formation on alumina surfaces. Langmuir 1995; 11 : 1443-1447.

42. Glatzhofer D, Cho G, Lai C, et al. Polymerization and copolymerization of sodium 10undecen-1-yl sulfate in micelles and in admicelles on the surface of alumina. Langmuir 1993; 9: 2949-2954.

43. Lai C, O'Rear EA, Harwell $J$, et al. Adsolubilization of fluorocarbon alcohols into perfluoroheptanoate admicelles formed on alumina. Langmuir 1997; 13: 4267-4272.

44. Kitiyanan B, O'Haver J, Harwell J et al. Absolubilization of styrene and isoprene in cetyltrimethylammonium bromide admicelle on precipitated silica. Langmuir 1996; 12: 21622168.

45. Drach D, Rudzinski W, Narjiewics-Michaelek J. Theoretical modeling of ionic surfactant adsorption on mineral oxide surfaces. J. Dispersion Sci. Technol. 2000; 21: 683-710.

46. Somasundaran P, Huang L. Adsorption/aggregation of surfactants and their mixtures at solidliquid interfaces. Adv. Colloids Interface Sci. 2000; 88: 179-208.

47. Atkin R, Craig VSJ, Wanless EJ, et al. Mechanism of cationic surfactant adsorption at the solid-aqueous interface. Adv. Colloids Interface Sci. 2003; 103: 219-304.

48. See CH, O'Haver J. Atomic force microscopy characterization of ultrathin polystyrene films formed by admicellar polymerization on silica disks. J. Appl. Polym. Sci. 2003; 89: 36-46.

49. Yuan WL, O'Rear EA, Grady BP, et al. Nanometer-thick poly(pyrrole) films formed by admicellar polymerization under conditions of depleting adsolubilization. Langmuir 2002; 18 : 3343-3351.

50. Yuan WL, O'Rear EA, Cho G, et al. Thin polypyrrole films formed on mica and alumina with and without surfactant present: characterization by scanning probe and optical microscopy. Thin Solid Films 2001; 385: 96-108.

51. Hamada H, Maekawa Z, Ikegawa N. Influence of surface treatment on impregnating property and mechanical properties of structural resin transfer molding composites. J. Mater. Sci. Soci. Japan 1994; 43: 229-234.

52. Ootsuka T, Hamano K, Kurano M, et al. Effect of heat treatment on the tensile strength of $\mathrm{Al}_{2} \mathrm{O}_{3}-\mathrm{SiO} 2$ glass fibers . J. Ceramic Soc. Japan 1997; 105: 175-178.

53. Naik NK. Woven Fabric Composites. Technomic Publishing Co. Inc.: Lancaster; 1994.

54. Higo M, Lu X, Mazur U, et al. Atomic force microscopy observation of the morphology of tetracyanoquinodimethane (TCNQ) deposited from solution onto the atomically smooth native oxide surface of Al(111) films. Thin Solid Films 2001; 384: 90-101.

55. Hamidi YK, Dharmavaram S, Aktas L, et al. Effect of fiber content on void morphology in resin transfer molded E-glass epoxy composites. J. Engr. Mat. Technol. 2009; 131: 21014 (111).

56. Hamidi YK, Aktas L, Altan MC. Effect of Packing on Void Morphology. Polym. Comp. 2005; 26: 614-627.

57. Gantchev B, Mihailov M. Electronic absorption spectroscopy of liquid systems containing polystyrene and polyacrylonitrile 1. Individual polymer solutions. Polym. Bull. 1998; 41: 207213.

58. Wei X, Carswell ADW, Alvarez W, et al. X-ray photoelectron spectroscopic studies of hydrophilic surfaces modified via admicellar polymerization. J. Colloid and Interface Sci., 2003; 264: 296-300.

59. Li T, Zhou C, Jiang M. UV absorption spectra of polystyrene. Polym Bull. 1991; 25: 211-216. 
60. Thomason JL, Schoolenberg GE. An investigation of glass fibre/polypropylene interface strength and its effect on composite properties. Compos. 1994; 25: 197-203.

61. Thomason JL, Dwight DW. The use of XPS for characterisation of glass fibre coatings. Compos. A 1999; 30: 1401-1413.

62. Thomason JL, Dwight DW. XPS analysis of the coverage and composition of coatings on glass fibres. J. Adh. Sci. Technol. 2000; 14: 745-764.

63. Pongprayoon T, O'Rear EA, Yanumet N, et al. Wettability of cotton modified by admicellar polymerization. Langmuir 2003; 19: 3770-3778.

64. Yang MW, Lin SY, A method for correcting the contact angle from the $\theta / 2$ method. Colloids and Surfaces A: 2003; 220, 199-201.

65. Green PF, Limary R. Block copolymer thin films: pattern formation and phase behavior. Adv. Colloid Interface Sci. 2001; 94: 53-81.

66. Masson JL, Green PF. Pattern formation in a thin random copolymer film: Evolution of an intermediate morphology. J. Chemical Phys. 2000; 112: 349-355.

67. Schutte CL. Environmental durability of glass-fiber composites. Mater. Sci. Engr. Reports 1994; R13: 265-323.

68. Larson B, Drzal L. Glass fibre sizing/matrix interphase formation in liquid composite moulding: effects on fibre/matrix adhesion and mechanical properties. Compos. 1994; 25: 711721.

69. Rao KJ. Structural Chemistry of Glasses. Elsevier: Amsterdam; 2002. Chapter 10, Elastic properties and pressure effects; p. 401-427.

70. Kim JK, Mai YW. Engineered Interfaces in Fiber Reinforced Composites. Elsevier: Amsterdam; 1998.

71. Hashimoto K, Fujisawa T, Kobayashi M, et al. Graft copolymerization of glass fiber and its application. J. Appl. Polym. Sci. 1982; 27: 4529-4539. 